East African Medical Journal Vol. 80 No. 7 July 2003

TEN-YEAR MORTALITY IN A PIONEER PSYCHIATRIC HOSPITAL IN WEST AFRICA

I.O. Malomo, MBBS, DPM, FMCPsy, FWACP, Consultant Psychiatrist/ Medical Director, Psychiatric Hospital, Yaba, Lagos, Nigeria, O. F. Aina, MBBS, FWACP, Lecturer/Consultant Psychiatrist, Department of Psychiatry, College of Medicine, University of Lagos, Lagos, Nigeria, H. T. O. Ladapo, MD (Ukraine), FMCPsych, FWACP, Consultant Psychiatrist/ Director of Clinical Services, Psychiatric Hospital, Yaba, Lagos, Nigeria, and A. O. Owoeye, MBChB, Senior Registrar in Psychiatry, Psychiatric Hospital, Yaba, Lagos, Nigeria

Request for reprints to: Dr. O. F. Aina, Department of Psychiatry, College of Medicine, University of Lagos, PMB 12003, Lagos, Nigeria

\title{
TEN-YEAR MORTALITY REVIEW IN A PIONEER PSYCHIATRIC HOSPITAL IN WEST AFRICA
}

\author{
I.O. MALOMO, O.F. AINA, H.T.O. LADAPO and A.O. OWOEYE
}

\begin{abstract}
Objective: To determine the mortality among admitted patients in the study centre, a pioneer psychiatric facility in the West African sub-region.

Design: A detailed retrospective study of the records of all deaths among the inpatients during the ten-year period of January, 1991 to December, 2000.

Setting: Psychiatric Hospital Yaba, Lagos, Nigeria; established in 1907 with present bed status of 535 and patronage from Lagos and it's environ, including the neighbouring Benin Republic.

Subjects: Ninety six patients that died while on admission in the centre during the study period.

Results: A total of 96 patients died over the ten-year period, giving an annual rate of 9.6. The age range was 14-87 years, and mean of 44.4 ( $\mathrm{SD} \pm 16.8)$ years. The male: female ratio was 1:1.6. Schizophrenia (26\%) and major depression (25\%) constituted the main psychiatric diagnoses at the time of admission among the cohort. The commonest cause of death included infections/infestations, most especially malaria and septicaemia (44\% of the cohort).

Conclusion: It is concluded that the major psychotic disorders, schizophrenia and depression continue to constitute the highest psychopathologies diagnosed psychiatric mortality study. Finally, infections/infestations still continue to play leading role as major causes of death in the West African sub-region.
\end{abstract}

\section{INTRODUCTION}

It is well established that the risk of premature death or excess mortality among psychiatric patients is higher than in the general population (1-3). The causes of the excess mortality arise from the mental disorder itself, and the unhealthy way in which the mentally ill patients live (4). Studies from advanced countries on patients in mental hospitals showed the relative risk of death for all psychiatric diagnoses was two to three times that of the age-matched in the general population $(5,6)$. Schizophrenia and major depression are especially associated with high risk of death from suicide and accidents (unnatural causes); while deaths from natural causes are highest among patients suffering from organic mental disorder, mental retardation and epilepsy. Epilepsy is included because of the close link of some types with psychiatric illness (4).

In the past few years, psychiatric case registers have uniquely been used to carry out mortality studies of mentally ill patients from defined geographical areas in advanced countries with up to date demographic data and well established community, mental health services (7). The same cannot be said for developing countries such as Nigeria where there is paucity of vital statistics and lack of comprehensive death register of the communities. In essence, as it was done in this review, mortality studies can only be carried out by periodic review of deaths in various medical institutions or their, departments (8-10).

Finally, mortality studies in psychiatry, is important from two perspectives: one, it provides information about the natural course of disorders; and, secondly, mortality data can be useful at identifying high-risk groups of psychiatric practice $(11,12)$.

\section{MATERIALS AND METHODS}

The study was carried out at Psychiatric Hospital, Yaba, Lagos, Nigeria. It was established in 1907 as one of the pioneer psychiatric facilities in the country then, known as Yaba Lunatic Asylum (13). Over the years, the hospital has undergone a lot of expansion and modernisation to its present 535 bed status with various training programmes including post graduate psychiatric residency in place. There is a high bed occupancy rate, with a lot of pressure on the outpatient clinic facilities from the teeming population of Lagos and its environs.

This was a retrospective study of all cases of death in the hospital over a ten-year period (January 1991 to December 2000). The well-kept records on the dead patients were retrieved from the special vault of the medical records department for detailed analysis. Demographic and other necessary data such as sex, age at death; duration of stay on admission before death, psychiatric diagnosis, cause(s) of death and autopsy findings (if performed) were obtained. The seven recorded cases of brought- 
in-dead (BID) during, the study period were excluded from analysis.

The data obtained was analysed using SPSS on IBM compatible PC to obtain appropriate statistical variables.

\section{RESULTS}

A total number of 96 deaths occurred during the tenyear period, giving an annual rate of 9.6; and this constituted $0.84 \%$ of the total admission for the period (Table 1 and Figure 1).

\section{Table 1}

Number of patients admitted and yearly mortality distribution

\begin{tabular}{|c|c|c|c|c|c|}
\hline \multirow[t]{2}{*}{ Year } & \multirow{2}{*}{$\begin{array}{c}\text { Total no. } \\
\text { of admission }\end{array}$} & \multicolumn{3}{|c|}{ No. of Deaths } & \multirow{2}{*}{$\begin{array}{c}\text { Death/ } \\
\text { Admission(\%) }\end{array}$} \\
\hline & & Male & Female & Total & \\
\hline 1991 & 1536 & 1 & 2 & 3 & 0.20 \\
\hline 1992 & 1352 & 3 & 2 & 5 & 0.37 \\
\hline 1993 & 1186 & 1 & 4 & 5 & 0.42 \\
\hline 1994 & 694 & 4 & 2 & 6 & 0.86 \\
\hline 1995 & 345 & 5 & 4 & 9 & 2.61 \\
\hline 1996 & 1185 & 2 & 7 & 9 & 0.76 \\
\hline 1997 & 1270 & 8 & 10 & 18 & 1.42 \\
\hline 1998 & 1238 & 4 & 13 & 17 & 1.37 \\
\hline 1999 & 1249 & 3 & 7 & 10 & 0.80 \\
\hline 2000 & 1310 & 6 & 8 & 14 & 1.07 \\
\hline Total & & 37 & 59 & 96 & \\
\hline
\end{tabular}

The age range was $14-87$ years, with the mean of 44.4 $(\mathrm{SD} \pm 16.8)$ years. There were thirty seven males $(38.5 \%)$ and fifty nine females $(61.5 \%)$, giving an $\mathrm{M}$ : F ratio of 1:1.6. Close to two-thirds $(67.7 \%)$ of the cohort was young adulthood/middle age (16-55 years) (Table 2 and Figure 2).
Table 2

Mortality by age and sex distribution

\begin{tabular}{lcccc}
\hline Age (years) & Male & Female & Total & $\%$ \\
\hline$\leq 15$ & 1 & - & 1 & 1.0 \\
$16-25$ & 5 & 5 & 10 & 10.4 \\
$26-35$ & 11 & 16 & 27 & 28.1 \\
$36-45$ & 4 & 8 & 12 & 12.5 \\
$46-55$ & 6 & 10 & 16 & 16.7 \\
$56-65$ & 4 & 13 & 17 & 17.7 \\
$>65$ & 6 & 7 & 13 & 13.6 \\
\hline Total & 37 & 59 & 96 & 100 \\
\hline
\end{tabular}

About $72 \%$ died within two weeks of hospitalisation, while $5.2 \%$ were chronically institutionalised patients that had spent over five years in the hospital.

Psychiatric diagnoses. The diagnoses of schizophrenia and depression (mood disorder) were made in $26 \%$ and $25 \%$ respectively; and these together constituted slightly over half of the cohort. Other forms of psychoses, mostly delusional disorder and undifferentiated type constituted 18.7\%; while $11.5 \%$ were cases of acute organic brain syndrome (Table 3 ).

Causes of death: The highest cause of death (44\%)was due to infections/infestations, especially malaria and septicaemia. This was followed by cardiovascular disorders, notably cases of sudden death, and hypertension with its attendant complications in $13.5 \%$ of the cohort. Diseases of the digestive system, mostly intestinal obstruction and gastroenteritis made up $8.4 \%$ of the mortality. Neurological and respiratory diseases that included meningitis, seizures, pulmonary tuberculosis constituted $7.3 \%$ each of these two systems for the mortality figure (Table 4).

Figure 1

Yearly and sex distribution of deaths 
Figure 2

Age distribution of deaths

Table 3

Mortality by sex and psychiatric diagnosis

\begin{tabular}{lcccc}
\hline Diagnosis & Male & Female & Total & $\%$ \\
\hline Schizophrenia & 6 & 19 & 25 & 26.0 \\
Mood Disorder & 4 & 20 & 24 & 25.0 \\
$\begin{array}{l}\text { Other } \\
\text { Psychoses }\end{array}$ & 11 & 7 & 18 & 18.7 \\
$\begin{array}{l}\text { Acute Brain } \\
\text { Syndrome }\end{array}$ & 7 & 4 & 11 & 11.5 \\
$\begin{array}{l}\text { Dementia } \\
\text { "Others" }\end{array}$ & 6 & 1 & 7 & 7.3 \\
\hline Total & 37 & 8 & 11 & 11.5 \\
\hline
\end{tabular}

N.B: "Others" include Drug abuse/dependence, Seizure disorder, personality disorders etc.

There were two cases of suicide $(2.1 \%)$ from selfpoisoning; with the psychopathologies of severe depression and paranoid schizophrenia respectively. Consent could not be obtained to perform post-mortem of any of the cohort except the two cases of suicide.
Table 4

Causes of death and sex distribution

\begin{tabular}{|c|c|c|c|c|c|}
\hline $\begin{array}{l}\text { Cause of } \\
\text { Death }\end{array}$ & $\begin{array}{c}\text { ICD-9 } \\
\text { Code No. }\end{array}$ & Male & Female & Total & $(\%)$ \\
\hline Infection & $000-136$ & 12 & 30 & 42 & 43.8 \\
\hline $\begin{array}{l}\text { Cardiovascular } \\
\text { disease }\end{array}$ & $390-429$ & 6 & 7 & 13 & 13.5 \\
\hline $\begin{array}{l}\text { Digestive } \\
\text { disease }\end{array}$ & $520-577$ & 2 & 6 & 8 & 8.3 \\
\hline $\begin{array}{l}\text { Neurological } \\
\text { disease }\end{array}$ & $320-389$ & 6 & 1 & 7 & 7.3 \\
\hline $\begin{array}{l}\text { Diabetes } \\
\text { Mellitus }\end{array}$ & 250 & 2 & 2 & 4 & 4.2 \\
\hline $\begin{array}{l}\text { Cerebrovascular } \\
\text { disease }\end{array}$ & $430-438$ & 1 & 2 & 3 & 3.1 \\
\hline $\begin{array}{l}\text { Genitourin- } \\
\text { ary disease }\end{array}$ & $580-629$ & 1 & 2 & 3 & 3.1 \\
\hline $\begin{array}{l}\text { Respiratory } \\
\text { disease }\end{array}$ & $460-519$ & 6 & 1 & 7 & 7.3 \\
\hline $\begin{array}{l}\text { Malignant } \\
\text { Neoplasm }\end{array}$ & $140-209$ & - & 1 & 1 & 1.0 \\
\hline Suicide & E950-959 & 1 & 1 & 2 & 2.1 \\
\hline Others & & - & 6 & 6 & 6.3 \\
\hline Total & & 37 & 59 & 96 & 100 \\
\hline
\end{tabular}

N.B: Others include Neuroleptic Malignant Syndrome (NMS), malnutrition with anaemia etc. 


\section{DISCUSSION}

As part of the multi-faceted efforts to improve quality health care, the hospital authority has taken the bold step to allow this maiden mortality review in a large psychiatric facility in Nigeria. Mortality studies constitute one of the important audit tools aimed at improving health care delivery services $(5,10-12)$. Although the total admission during the 10 year study period was 1:1.35 for female: male ratio, yet the female: male mortality ratio for the same period was 1.6:1. Our finding was contrary to that of some previous similar studies where greater mortality was found for men $(6,7)$. This can possibly be explained by the fact that in the study, excess females (13) compared to males (10) suffered from schizophrenia or depression as the underlying psychopathology. These two mental illnesses when compared to others are associated with unduly increased risk of premature death from both natural and unnatural causes $(5,6,12)$.

Furthermore, studies have shown that the greater risk of mortality associated with major depression can be attributed to the poor level of physical functioning of the depressed patients (14). It has also been hypothesized that psychiatric conditions most especially schizophrenia and depression are precursors to organic pathologies $(11,12)$, probably due to the poor healthy way such patients elect to live(4) but; the final biological pathways are poorly understood $(15,16)$. More recent studies tend to further reinforce our finding, as women are now known to experience worse physical and mental health than men (16), and especially in developing countries, women's timely access to health care is limited (17), thus, raising the risk of greater mortality in women.

Infections/infestations especially malaria and typhoid constituted the highest cause of death in the cohort (52.1\%). Inadequate sanitation and poor socio-economic conditions among other factors make infections /infestations to be highly endemic in Africa and retain a leading role at causing death (10, 18-20). Cardiovascular disorders take a distant trail (13.5\%, after infections/infestations as the cause of mortality in the study. Eight of the thirteen deaths from cardiovascular problems were cases of sudden, unexpected deaths. There have been lots of reports of sudden, unexplained death among patients on antipsychotic drugs $(21,22)$, and this is attributed to drug-induced arrhythmia caused by the antipsychotics, similar to the cardiac electrophysiological effects of quinidine (23). Torsade de pointes (a polymorphic ventricular arrhythrmia), recorded on patients with antipsychotic overdose (24), provide a clue to the mechanism of sudden, unexplained death among patients on antipsychotic therapy (25). Systemic hypertension and its complications constituted the rest cardiovascular deaths in the cohort. Hypertension, with its complications is one of the leading causes of cardiovascular morbidity and mortality in Nigeria (26).

Diabetes mellitus, cerebrovascular accident (CVA), gastroenteritis and pulmonary tuberculosis were the other common causes of death in the cohort. CVA or stroke as a complication of hypertension and/or diabetes is a common neurological problem in Africa(27), and accounts for about $4.5 \%$ of all deaths in hospital based studies in Nigeria (28). Gastroenteritis and pulmonary tuberculosis are leading causes of gastrointestinal and respiratory deaths in developing countries; and their increased incidences is attributed to poor sanitation, overcrowding, malnutrition and due to the recent upsurge in the endemicity of HIV/ AIDS complex $(8,29)$.

The finding of only two cases of suicide in the cohort over the ten year period is, contrary to that in developed countries where there are increased reports of suicide by, in-patients in psychiatric hospitals(30). However, generally, in Nigeria there are low rates for suicide(31). Except for medico-legal cases such as suicide as in this study where it is mandatory, post-mortem is greatly resented in Africa due to religious and cultural practices(10).

Finally, it is highly commendable that some steps have been taken to improve quality patient care in the study centre following the regular in-house mortality reviews and the preliminary analysis of this data. Such steps include regular seminars for health care workers in the hospital on the management of patients with coexisting physical pathology, appropriate referral services to transfer patients with complicated organic pathologies to neighbouring teaching/general hospitals and the employment of part time consultant physicians (a neurologist and a cardiologist). All these are aimed at further reduction in the mortality figure to the barest minimum in the study centre.

\section{ACKNOWLEDGEMENTS}

To the medical records department for their commendable assistance. Special thanks to the top management committee (TMC) of the hospital for the permission to carry out this study. We are also grateful to members of the research group in the centre for their constructive criticisms of the earlier draft of this manuscript.

\section{REFERENCES}

1 Sims, A. Why the excess mortality from psychiatric illness? Brit. Med. J. 1987; 294: 986-987.

2. Sohlman, B. and Lehtinen, V. Mortality among discharged psychiatric patients in Finland. Acta. Psychiatr. Scand. 1999; 99:102-109.

3. Joukamaa, M., Hehövaara, M., Knekt P., Aromaa A., Raitasalo R. and Lehtinen V. Mental disorders and cause specific mortality. Brit. J. Psychiatry, 2001; 179: 498-502.

4. Harris, E.C. and Barraclough, B. Excess mortality of mental disorder. Brit. J. Psychiatry. 1990; 173:11-53.

5. Innes, G. and Millar, W.M. Mortality among psychiatric patients. Scott. Med. J. 1970; 15: 143-148.

6. Sims, A. Mortality statistics in psychiatry. Brit. J. Psychiatry. 2001; 179: 477-478.

7. Amaddeo, F., Bisoffi, G., Bonizzato, P., Micciolo, R. and Tansella, M. Mortality among patients with psychiatric illness: A ten-year case register study in an area with a community-based system of care. Brit. J. Psychiatry. 1995; 166: $783-788$. 
8. Adetuyibi, A., Akinsanya, J.B. and Onadeko, B.O. Analysis of the causes of death on the medical wards of the University College Hospital, Ibadan over a 14 year period, 1960-1974. Nig. Med. J., 1978; 8: 28-34.

9. Lamikanra, O.T. The register of mortality in Lagos. A brief review. Nig. Med. J. 1994; 26: 1-4.

10. Adesunkanmi, A. R. K., Akinkuolie, A.A. and Badru O.S. A five-year analysis of death in accident and emergency room of a semi-urban hospital. West Afr. J. Med. 2002; 21: 99-104

11. Tsuang, M.T., and Simpson, J.C. Mortality studies in psychiatry. Arch. Gen. Psychiatry, 1985; 42: 98-103.

12. Bruce, M.L., Leaf, P. J. Rozal, G.P.M., Florio, L. and Hoff, R.A. Psychiatric status and 9 year mortality data in the New Haven epidemiologic catchment area study.Am. J. Psychiatry, 1994; 151: 716-721.

13 Boroffka, A. The history of mental hospitals in Nigeria: In Benier P., Wolf R. and Thau K. (eds) psychiatry. Vol. 8 Plenum Publishing Corporation, 1985; 37-43.

14. Wells, K.B. Stewart, A., Hays R.D., et al. The functioning and well-being of depressed patients. Results from the medical outcome study. JAMA 1989; 262: 914-919.

15. Katon, W., and Sullivan, M.D. Depression and chronic medical illness. J. Clin. Psychiatry, 1990; 51: (June suppl.)3-11.

16. Rodin, J., and Ikovics, J. Women's health: review and research agenda as we approach the 21st century. Am. Psychol., 1990; 45: 1018-1034.

17. Blumenthal, S.J. Improving women's mental and physical health: Federal initiative and programmes In John M. Oldham and Michelle B. Riba (eds): Review of psychiatry.American Psychiatric Press Inc. Washington D.C. London, England. 1995; 14:181-204.

18. W.H.O. World Health Statistics Reports, Geneva,1976; 29: 37-38.

19. Lorman, G.G. Helicobacter pylori: fact or fiction. Scand. J. Gastroenterol. 1990; 87: 28-30.
20. Tanyigna, K.B., Ayeni, J.A., Okeke, E.N. Onah, J.A., and Bello C.S.S. Baseline antibody levels of salmonella typhi and paratyphi in a Nigerian town. East Afr. Med. J. 1999; 76: 19-21.

21. Barnette, A.A. Safety concerns over antipsychotic drug, sertindole. Lancet. 1996 348: 256

22. Waddington, J.L., Youseff, H.A. and Kinsella, A. Mortality in schizophrenia Antipsychotic polypharmacy and absence of adjunctive anticholinergies over the course of a 10-year prospective study. Brit. J. Psychiatry. 1998; 173: 325-329.

23. Thomas, S.H. and Drugs, Q.T. Interval abnormalities and ventricular arhythmias. Adverse Drug React. Toxicol. Rev. 1994; 13:77-102.

24. Henderson, R.A., Lane S., and Henry, J.A. Life-threatning ventricular arrhythmias (torsade de pointes) after haloperidol overdose. Hum. Exp. Toxicol. 1991; 10: 59-62

25. Liberatoe, M.A., and Robinson, D.S. Torsade de pointes: a mechanism for sudden death associated with neuroleptic drug therapy. J. Clin. Psychopharmacol. 1984; 4:143-146.

26. Aderibigbe, A., Omotosho, A.B.O., Awobusuyi, J. O. and Akande T.M. Arterial blood pressure in adult Nigerian sickle cell anaemia patients. West Afr.J. Med. 1999; 18: 114-118.

27. Abraham, I.G., and Abdulkadri, J. Cerebrovascular accident in Ethiopians, a review of 48 cases. East. Afr. Med. J. 1981;58:431436.

28. Ogun, S.A., Oluwole, O., Ogunseyinde, A.O., Fatade, B. and Odusote, K.A. Misdiagnosis of Stroke - A computerized Tomography Scan Study. West Afr.J. Med. 2000; 19: 19-22.

29. Dolin, P.J., Raviglione, M.C., and Kochi, A. Global tuberculosis incidence and mortality during 1990-2000. Bull. World Health Org. 1994; 72: 213-220.

30. Powell, J., Geddes, J., Hawton, K. et al. Suicide in psychiatric hospital In-patients. Risk factors and their predictive power. Brit. J. Psychiatry. 2000; 176: 266-272.

31. Eferakeya, A.E. Drugs and suicide attempt in Benin City. Nigeria. Brit. J. Psychiatry. 1984; 145: 70-73. 